\title{
University Information Environment: the Case Study
}

\author{
E. A. Lavrov \\ Sumy State University \\ Sumy, Ukraine \\ prof_lavrov@mail.ru
}

\author{
N. P. Pan
}

O.M.Beketov National University of Urban Economy

in Kharkiv

Kharkiv, Ukraine

pan@kname.edu.ua

\author{
P. I. Paderno ${ }^{1}$, A. A.Volosiuk ${ }^{2}$ \\ St. Petersburg Electrotechnical University "LETI" \\ St. Petersburg, Russia \\ 1'pipaderno@list.ru, 2aavolosiuk@gmail.com
}

\author{
O. E. Lavrova
}

Taras Shevchenko National University of Kyiv

Kiev, Ukraine

lavrova_olia@ukr.net

\begin{abstract}
The paper considers the issues of digitalized control of the university. The causes for the low efficiency of university digitalization development are revealed. Among the main issues are patchwork digitalization and ignoring the principles of modern quality management systems. The concept of designing an effective university information environment based on the philosophy of universal quality management, the methodology of integrated information systems, the principles of an active operator, adaptability and the human-system approach are described. The paper presents the university management information system tested at 20 universities in Russia and Ukraine. The system is useful not only to the university, but also to enterprises, since (1) it provides a higher quality of training, allowing creating "training paths" with production specifics taken into account, and (2) guarantees access to information about a future specialist.
\end{abstract}

Keywords-control systems; information systems; university; information environment; digitalization; automation; ergonomics; e-learning; adaptation; quality control

\section{INTRODUCTION}

The rapid progress of information and communication tools has sparked a surge of interest in:

- Information technology management higher education;

- Training digitalization.

Digital technologies for lifelong learning are spreading [1].

Computer training has evolved from "episodic use of technical tools for training and knowledge control", as well as from systems such as "Dean's office" or "Department" (50s 90 s of the 20th century) to the development of unified information environments of universities, for example [2, 3]. Moreover, both stationary computers and mobile devices of the educational process participants are accessing the universities information environments and controlling the relevant processes $[4,5]$.
Universities are increasingly introducing technologies for managing the activities of teachers, staff, as well as e-learning and blended systems for the educational process organization $[6,7]$.

\section{PROBlEM ANALYSIS AND RESEARCH GoAls SETTING}

University activities digitalization has become a global trend; enormous resources are allocated for the creation of new technologies, for example [3], but the return on efforts and capital investments (in the sense of a stepwise improvement in management quality indicators and the educational process efficiency) often do not meet the expectations of the educational process participants $[8,9]$. The existing hypothesis "Total automation of all existing processes in a university and the accumulation of relevant information in databases can significantly increase the university activities efficiency" is not only not working in practice, but also is harmful. New digital tools, communication channels, and advanced technologies implemented without a thorough system analysis, can lead to an avalanche-like increase in the number of issues, for example, [8, 9] and in the risks of various threats to people's safety, for example [10].

The goals for the presented work are:

- Analysis of the causes for the low efficiency of higher education institution information management systems;

- Description of methodological and scientific-practical principles for university information systems building, based on many years of work in development, implementation and operation of such systems.

\section{INFORMATION ENVIRONMENT AS A UNIVERSITY ACTIVITY QUALITY MANAGEMENT TOOL}

A. Justification of the Research Concept

The work is based on: 
- A summary of our 26 years of experience in researching automated university management systems:

- Review of literary sources describing university management systems in Europe, North America, Australia [1, 3-11] and others;

- Inspection of acting systems - Ukraine, Russia [2, 12-17], and others;

- Generalization of the own experience [13] in university management systems development and implementation for more than 20 higher educational institutions;

- Methodology of Total Quality Management (TQM) $[11,13,14]$ specifically adapted to higher educational institutions activities;

- Methodology of the "active operator" and the humansystem approach to process control in ergotechnical systems $[12,18]$;

- Methodology of "adaptive systems" [18] (in terms of adaptation in the features of all types of operators working in the complex hierarchical human-machine system "University") [13].

\section{B. Analysis of the main problems of existing systems}

The main problems of existing systems are:

- Pr1 - "patchwork automation" with many heterogeneous systems and subsystems, which are often duplicating each other's functionality, working in the interests of specific departments, and may even need operators to work in different subsystems;

- $\quad \operatorname{Pr} 2$ - data duplication and inconsistency (as a result of Pr1);

- Pr3 - ignoring the principles of the process approach, process automation "as is";

- Pr4 - lack of full integration of the "Administration" and "Teaching" subsystems (as a result of Pr1);

- $\quad$ Pr5 - lack of moral and pragmatic interest of staff and teachers to work with the proposed tools;

- $\quad$ Pr6 - low quality of the digital training resources, lack of efficiency in content management;

- $\quad$ Pr7 - low development of adaptation mechanisms to the characteristics of the system operators - students, staff, teachers;

- $\quad \operatorname{Pr} 8$ - low efficiency and quality of process tracking and presentation of the whole complex of necessary information in the university portal system (schedule, digital log books, ratings, etc.), issues with supporting mobile devices interface;

- $\operatorname{Pr} 9$ - focus on powerful software environments, which are usually designed for industrial information systems (such as SAP R3), with the hope of "adapting" the environments to university specifics someday in the future, which, as a rule, is rarely possible, especially for outsourced software developers;

- $\operatorname{Pr} 10$ - lack of both interest and process continuous monitoring by the leading manager;

- Other.

Today almost all higher educational institutions report the success of digitalization and e-learning, but for many it is simply a tribute to fashion and the digitalization is often inefficient. The haphazard accumulation of low-quality electronic resources is much more harmful than even an old paper textbook and a traditionally oriented teacher.

For TOP universities that have made a breakthrough in digitalization, now comes a period of new strategies development for advanced adaptation to the technological Digital Revolution.

\section{Methodology for creating and operating the information environment}

Based on the analysis, the we propose the following methodological principles:

Mp1. Focus on the use of Total Quality Management (TQM) philosophy. Among the basic principles of TQM $[11,13,14]$ :

- Customer focus;

- Staff involvement;

- Process approach;

- System unity;

- Strategic and systematic approach;

- Continuous improvement;

- Factual decision making;

- Communications.

Mp2. Integration. Integrated Automated Control System (ACS) is distinguished by the design method that ensures the consistent achievement of goals, each of which cannot be achieved through the local use of individual types of ACS. In mechanical engineering, an integrated ACS (IACS) includes:

- Computer-Aided Design (CAD) systems;

- Automated systems for production technological preparation (ASPTP);

- $\quad$ Production ACS (PACS);

- $\quad$ Automated Process Control Systems (APCS).

Similar processes should be automated in a university management system, which in the general case consists of two global subsystems: "University Activities Management", "Teaching Process Management". 
Thus, in an integrated ACS:

- Both global subsystems should be implemented within a single system (information environment);

- Comprehensive digitalization should cover all stages of the life cycle of all functional elements of all subsystems.

Mp3. Adaptability. The requirement for adaptability is relevant due to massive refusal of students to work with digital software tools that are uncomfortable for them personally. The essential characteristics of the trainees and the environment should be promptly taken into account for each dialogue session. At the same time, the adaptation should be carried out for:

- Modalities;

- Complexity of the material;

- Algorithms for human-machine interaction;

- Student motivation;

- Available time resource;

- Student functional state.

Mp4. Ergonomics. A digitalized university essentially becomes a polyergatic information system with different types of operators (managers, administrators, teachers, attendants, students, etc.).

Nowadays unfortunately, most of the university operators work under stress conditions, high workload and cognitive discomfort. Therefore, we believe that special ergonomics departments or ergonomic support sectors should be created at universities as a part of digitalization services that would professionally deal with ergonomic quality problems.

Such services should provide:

On the university management tasks level:

- Information environment optimization based on the principles of a "distributed authority" system, certification of workplaces for operators and software, elimination of "patchwork automation" [23-27];

- Automation levels optimization for each specific task [13];

- $\quad$ Tasks optimal distribution among performers [13, 21];

- Optimization of interface solutions for operators' workplaces, taking into account their psychophysiological characteristics and functional responsibilities [12, 13];

- Interfaces assessment, workload analysis, application queues, work intensity, stresses, work and rest regimes, etc.) $[13,16,17]$;

On the e-learning management tasks level:

- Development of engineering-psychological and design requirements for content $[19,20]$;
- Content assessment and modernization of electronic training modules [19];

- Development of technologies for providing individual training paths $[12,22,24]$;

- Monitoring the functional state of students [12, 16, 19];

- Providing mechanisms for adapting the information system to the preferences and psychophysiological characteristics of students and current environmental parameters $[12,19]$;

- Implementation and ergonomic analysis of the "intelligent agents" system performance efficiency [19].

\section{Implementation and approbation}

Initially, the methodology was used in developing and implementing (under the technical guidance of Ph.D. Klimenko A.V.) the system "Computer Management of a University" [13] at Sumy National Agrarian University and Kharkiv National Academy of Municipal Economy.

Decisions and approach efficiency approval allowed to extend the experience in developing university automation systems in more than 20 universities in Ukraine and Russia (Moscow, Belgorod, Kharkov, Kremenchug, Vinnitsa, Zhytomyr and others, including Lomonosov Moscow State University).

The fundamental differences of the implemented systems are:

- Holism of the hierarchical system of management, control, information, and training functions with taking into account the needs of all structural units (rector, vice-rectors, academic departments, planning and financial departments, human resources department, dean's offices, departments to dormitories, etc.) with the comprehensive workflow automation and automatic generation of all types of orders, statements, protocols, etc.;

- Automatic generation of all types of schedules with an extensive system of accounting capabilities and online informing the participants of the educational process;

- Flexible adaptation to the specifics of the university, as well as individual requests and psychophysiological characteristics of users.

- Possibility for enterprises (employers) representatives to participate in organization and control of all elements of the educational process.

\section{CONCLUSIONS}

High efficiency of automated university management can be achieved by focusing on the use of the methodology of Total Quality Management by ensuring the properties of integration, ergonomics, and adaptability. 
The proposed technology can be useful in developing the information environments for modern universities and will be the basis for training specialists quality management systems, as well as will ensure (on the basis of the cybernetic models) close "university - enterprise" cooperation, focused on the specialist training model design, meeting the requirements of a particular production.

\section{REFERENCES}

[1] L.M. Blaschke. "Heutagogy and lifelong learning: A review of heutagogical practice and self-determined learning". The International Review of Research in Open and Distributed Learning, Vol. 13, Issue 1, 2012, P. 56. doi: 10.19173/irrodl.v13i1.10762.

[2] G.V. Verkhova, S.V. Akimov. "Electronic educational complex for training specialists in the field of technical systems management," in Proceedings of IEEE II International Conference on Control in Technical Systems (CTS), 2017, pp. 26-29.

[3] D. Joshua. "E-Learning platform system for the department of library and information science, Modibbo Adama University of Technology, Yola: A Developmental plan". Information Impact: Journal of Information and Knowledge Management, Vol. 7, Issue 1, 2016, pp. 5169.

[4] T. Cochrane, V. Narayan, J. Oldfield . "iPadagogy: Appropriating the iPad within pedagogical contexts". International Journal of Mobile Learning and Organisation, vol. 7, issue 1, 2013, P. 48. doi: 10.1504/ijmlo.2013.051573

[5] O.R.E. Pereira and J. J. P. C. Rodrigues. "Survey and analysis of current mobile learning applications and technologies". ACM Computing Surveys, vol. 46, issue 2, 2013. - P. 35. doi: 10.1145/2543581.2543594

[6] A.A.Y. AlQahtani and S.E. Higgins "Effects of traditional, blended and e-learning on students' achievement in higher education" . Journal of Computer Assisted Learning, vol. 29, issue 3, 2012, pp. 220-234. doi: 10.1111/j.1365-2729.2012.00490.x

[7] P. Semingson, M. Crosslin and J. Dellinger "Microlearning as a tool to engage students in online and blended learning ", in Proc of Society for Information Technology \& Teacher Education International Conference, 2015,pp. 474-479.

[8] P. Jandric and D. Boras. "Critical Learning in Digital Networks, Research in Networked Learning". Springer International Publishing Switzerland, 2015, P.241. doi: 10.1007/978-3-319-13752-0

[9] T. Cochrane. "Secrets of mlearning failures: confronting reality". Research in Learning Technology,vol. 20, 2012 - pp. 123-134

[10] E. Etelson. "Is modern technology killing us?" . Truthout, 2014. Available at: http://www.truth-out.org/opinion/item/26295-is-moderntechnology-killing-us

[11] B.H.S. Thimmappa, F.G. Motlagh, D.K. Shetty, B. Rajendra, A.S. Pai and L.L.R. Rodrigues, "Development of an Integrated Knowledge and Technology Management Model for the Higher Education," 2019 International Conference on Automation, Computational and Technology Management (ICACTM), London, United Kingdom, 2019, pp.288-292. doi: 10.1109/ICACTM.2019.8776777

[12] N.L. Barchenko. Erhonomichne zabezpechennia dialohovoi liudynomashynnoi vzaiemodii $\mathrm{v}$ modulnykh systemakh elektronnoho navchannia (Ergonomic support for human-machine interaction in modular learning systems) Dissertation, Kharkiv National University of Urban Economy, 2019.

[13] Lavrov E.A. and Klimenko A.V. Kompyuterizatsiya upravleniya vuzom [University management computerization]. Sumy, Ukraine: DovkIllya, 2005.

[14] E.V. Bagrova, S.V. Kruchinin and M.A. Nazarenko, "Quantity Measures of Quality in Higher Education in Russia. How Information Technologies Can Help?," 2018 IEEE International Conference "Quality
Management, Transport and Information Security, Information Technologies" (IT\&QM\&IS), St. Petersburg, 2018, pp. 557-560. doi: 10.1109/ITMQIS.2018.8525044

[15] L.N. Khramova., A.A. Tsakhaeva, A.V Posokhova., E.A. Lavrov, V.M Litvishkov and A.V. Vilkova. "Modern managers training in the context of competence approach". The Journal of Social Sciences Research, vol.S5, 2018, pp. 194-199. doi.10.32861/jssr.spi5.194.199

[16] O.Y. Burov, O.P. Pinchuk, M.A. Pertsev and Y.V. Vasylchenko "Using the students' state indices for design of adaptive learning systems". Information Technologies and Learning Tools, 68(6), 2018, pp. 20-32.

[17] O.Y. Burov. "ICT for performance assessment of emergent technologies operators", in Proceedings of the 13th International Conference on ICT in Education, Research and Industrial Applications. Integration, Harmonization and Knowledge Transfer, Kyiv, Ukraine, May 15-18, CEUR-WS 2017, Vol. 1844, 2017, pp. 127-138

[18] A.N. Adamenko, A.T. Asherov, I.L. Berdnikov et al. Informacionnoupravljajushhie cheloveko-mashinnye sistemy: Issledovanie, proektirovanie, ispytanija. Spravochnik [Information controlling humanmachine systems: research, design, testing. Reference book], A.I. Gubinsky \& V.G. Evgrafov, eds. Moscow, Russia: Mashinostroenie Publ., 1993. (In Russian).

[19] E. Lavrov and O. Lavrova "Intelligent adaptation method for humanmachine interaction in modular E-learning systems", in. Proceedings of the 15th International Conference on ICT in Education, Research and Industrial Applications. Integration, Harmonization and Knowledge Transfer. Volume II: Workshops, Kherson, Ukraine, June 12-15, 2019, pp.1000-1010.

[20] E. Lavrov, O. Kupenko, T. Lavryk and N. Barchenko. "Organizational Approach to the Ergonomic Examination of E-Learning Modules" Informatics in Education, vol. 12, no. 1, 2013, pp . 107-12

[21] V. Lubchak, O. Kupenko and B. Kuzikov "Approach to Dynamic Assembling of Individualized Learning Paths". Informatics in Education, vol. 11, no. 2, 2012, pp. 213-225

[22] E. Lavrov, N. Barchenko, N. Pasko and A. Tolbatov. "Development of Adaptation Technologies to Man-Operator in Distributed E-Learning Systems," in Proceedings of 2nd International Conference on Advanced Information and Communication Technologies-2017 (AICT-2017), Lviv, Ukraine, July 4-7, 2017, pp. 83-87

[23] E. Lavrov and N. Pasko. "Automation of Assessing the Reliability of Operator's Activities in Contact Centers that Provide Access to Information Resources," in Proceedings of the 14th International Conference on ICT in Education, Research and Industrial Applications. Integration, Harmonization and Knowledge Transfer, vol. I: Main Conference. - Kyiv, Ukraine, May 14-17, 2018, pp.445-448

[24] E. Lavrov, N. Barchenko, N. Pasko and I. Borozenec. "Development of models for the formalized description of modular e-learning systems for the problems on providing ergonomic quality of human-computer interaction." Eastern-European Journal of Enterprise Technologies. Ser. "Information technology", vol. 2/2 (86), pp. 4-13, 2017. doi: 10.15587/1729-4061.2017.97718

[25] E. Lavrov, A. Volosiuk, N. Pasko, V. Gonchar and G.Kozhevnikov. "Computer Simulation of Discrete Human-Machine Interaction for Providing Reliability and Cyber-security of Critical Systems," in Proceedings of the Third International Conference Ergo-2018: Human Factors in Complex Technical Systems and Environments (Ergo-2018) July 4 - 7, 2018, St. Petersburg Russia- 2018, pp.67-70. doi:10.1109/ERGO.2018.8443846

[26] P.C. Cacciabue. "Human error risk management for engineering systems: a methodology for design, safety assessment, accident investigation and training." Reliability Engineering \& System Safety, vol. 83, issue 2, pp. 229-269, 2014. doi: 10.1016/j.ress.2003.09.013.

[27] M. Havlikovaa, M. Jirglb and Z. Bradac. "Human reliability in manmachine systems," Procedia Engineering, vol. 100, 2015, pp. 1207 1214. doi.org/10.1016/j.proeng.2015.01.485 